\title{
MANIFEST ETNOLOGÓW I ANTROPOLOGÓW POLSKICH PRZECIW DYSKRYMINACJI
}

Jako przedstawiciele etnologii oraz antropologii społecznej i kulturowej czujemy szczególną odpowiedzialność za kształt wiedzy o kulturze i społeczeństwie. Niepokoją nas coraz liczniejsze przypadki manipulacji i ignorancji w tym obszarze, obecne w debacie publicznej, mediach, edukacji oraz polityce. Mamy na uwadze przede wszystkim bałamutne twierdzenia formułowane w odniesieniu do migracji, uchodźców, wielokulturowości oraz tożsamości narodowych, etnicznych czy religijnych. Z tych powodów za potrzebne i słuszne uznaliśmy zorganizowanie Nadzwyczajnego Zjazdu Etnologów i Antropologów Polskich oraz ogłoszenie niniejszego manifestu.

Wiedza o kulturze i społeczeństwie jest polem naszych kompetencji, powstałym dzięki wieloletnim badaniom i dziedzictwu dyscypliny uprawianej od ponad stu lat. Jesteśmy więc uprawnieni i zobligowani, by wypowiadać się w tym zakresie. Traktujemy to jako obowiązek wynikający z etosu antropologii - nauki służącej społeczeństwu i wartościom humanistycznym. Kieruje nami ponadto poczucie odpowiedzialności oraz postawa obywatelska.

Dlatego wyrażamy stanowczy sprzeciw wobec wszelkich przejawów dyskryminacji, wykluczania i mowy nienawiści na tle kulturowym, religijnym, etnicznym, genderowym bądź światopoglądowym. Protestujemy przeciwko świadomemu manipulowaniu faktami, ideologizowaniu przekonań, ksenofobii, rasizmowi oraz przemocy wymierzonej w ludzi reprezentujących odmienne kultury, tożsamości, postawy, wyznania i wartości. Przypadki takie, zdarzające się coraz częściej, godzą w podstawy ładu społecznego i prowadzą do ludzkich tragedii. Aby im przeciwdziałać, występujemy w obronie rzetelnej wiedzy o kulturze i społeczeństwie, wzywamy do wzajemnego szacunku oraz domagamy się respektowania wartości humanistycznych. Bronimy społeczeństwa otwartego i różnorodnego, budowanego w oparciu o ideały demokracji i prawa człowieka.

23.11.2016, Poznań
Uczestnicy Zjazdu 
